\title{
MENINGKATKAN PEMAHAMAN PESERTA DIDIK TERHADAP LAYANAN BK DENGAN MENGGUNAKAN VIDEO TIKTOK DI SMK NEGERI 4 PALANGKA RAYA
}

\author{
Zlkraiyah \\ SMK Negeri 4 Palangka Raya \\ E-mail: gt.zikra86@gmail.com /082350902848
}

\begin{abstract}
ABSTRAK
Layanan Bk di sekolah bertujuan untuk menyiapkan peserta didik secara psikologis untuk secara optimal dapat menerima pembelajaran di sekolah. Fenomena yang terjadi di SMKN 4 Palangka Raya banyak peserta didik yang memiliki pemahaman yang negatif terhadap layanan BK di sekolah yang menyebabkan peserta didik enggan untuk memanfaatkan layanan BK. Tujuan dari penelitian ini adalah untuk meningkatkan pemahaman peserta didik terhadap layanan Bk di sekolah. Metode yang digunakan adalah metode kualitatif dengan pendekatan penelitian tindakan bimbingan dan konseling (PTBK). Langkah-langkah penelitian dilakukan dengan siklus yang tiap siklusnya meliputi langkah perencanaan, tindakan, pengamatan dan refleksi. Teknik Pengumpulan datanya menggunakan wawancara, observasi dan angket. Hasil dari penelitian ini dengan 2 siklus di dapatkan hasil terdapat peningkatan pemahaman dari persentase angket sebesar $37 \%$. Sebelum dilakukan penelitian tingkat pemahaman peserta didik berada pada $52 \%$. Setelah diberikan intervensi dengan layanan informasi dengan mengggunakan video tiktok, terdapat peningkatan sebesar $89 \%$. Selain dengan angket, melalui observasi terlihat peserta didik aktif dan antusias dalam mengikuti kegiatan layanan informasi dengan video tiktok. Berdasarkan paparan tersebut, peneliti menyimpulkan bahwa layanan informasi dengan menggunakan video tiktok berhasil meningkatkan pemahaman peserta didik di SMK Negeri 4 Palangka Raya. Peneliti berharap peneliti selanjutnya dapat menjadikan referensi dan mengembangkan penggunaan video tiktok khususnya dalam meningkatkan pemahaman peserta didik.
\end{abstract}

Kata Kunci: Layanan Informasi; Whats App Group; Tiktok; Pemahaman Peserta didik

\section{IMPROVING STUDENTS' UNDERSTANDING OF BK SERVICES USING TIKTOK VIDEOS AT SMK NEGERI 4 PALANGKA RAYA}

\begin{abstract}
Guidance and Counseling (BK) services in schools aim to prepare students psychologically to optimally receive learning at school. The phenomenon that occurs at SMKN 4 Palangka Raya is that many students have a negative understanding of $B K$ services in schools which causes students to be reluctant to take advantage of BK services. The purpose of this research is to increase students' understanding of Bk services in schools. The method used is a qualitative method with a guidance and counseling action research approach (PTBK). The steps of the research are carried out in cycles, each of which includes planning, action, observation and reflection steps. Data collection techniques using interviews, observations and questionnaires. The results of this study with 2 cycles showed that there was an increase in understanding of the percentage of the questionnaire by $37 \%$. Prior to the research, the level of understanding of students was at $52 \%$. After being given an intervention with information services using tiktok videos, there was an increase of $89 \%$. In addition to the questionnaire, through observation, it was seen that students were active and enthusiastic in participating in information service activities with tiktok videos. Based on this explanation, the researcher concluded that information services using tiktok videos succeeded in increasing the understanding of students at SMK Negeri 4 Palangka Raya. Researchers hope that future researchers can make references and develop the use of tiktok videos, especially in improving students' understanding. Keywords: Information Services; Whatsapp groups; Tiktok; Student Understanding
\end{abstract}




\section{PENDAHULUAN}

Layanan Bimbingan dan Konseling merupakan bagian dari program sekolah yang memberikan layanan kepada peserta didik secara khusus dalam mengoptimalkan pemahaman, penerimaan diri, penyesuain diri dan lingkungannya ((Rahmawati \& Handoyo, 2020). Bimbingan dan konseling (BK) merupakan salah satu unsur penting di sekolah selain pemberian layanan pendidikan yang dilakukan oleh guru mata pelajaran. Tujuan pemberian layanan bimbingan dan konseling di sekolah untuk menyiapkan peserta didik siap secara mental atau psikologis untuk menerima pendidikan yang di berikan di sekolah. Selain itu peserta didik dapat menyesuaikan diri dengan lingkungan pendidikan, masyarakat, ataupun lingkungan kerja.

Layanan bimbingan dan konseling di sekolah dibagi ke dalam 4 (empat) ragam layanan bimbingan yaitu I) bimbingan akademik; 2) Bimbingan Pribadi sosial; 3) Bimbingan Karier; dan 4) bimbingan keluarga ((Nurihsan, 2016). Secara khusus bimbingan dan konseling di arahkan untuk membantu individu untuk dapat menghadapi ataupun mengatasi masalah-masalah akademik, pribadi sosial, karir dan keluarga. Bimbingan dan konseling diberikan agar peserta didik mencapai kemandirian hidup. Layanan tentunya akan diberika secara sistematis dan berkelanjutan di sekolah melalui program-program yang telah di rancang berdasarkan kebutuhan peserta didik.

Bimbingan dan konseling bukan kegiatan insindental yang hanya dilakukan ketika permasalahan muncul, akan tetapi bimbingan dan konseling melalui program yang dirancang di awal semester dengan memperhatikan segala aspek seprti kebutuhan individu, harapan dan kondisi lingkungan dengan melibatkan semua unsur mulai dari kepala sekolah, guru mata pelajaran, peserta didik dan orang tua. Adapun layanan yang diberikan di sekolah meliputi layanan konseling individual, konseling kelompok, bimbingan kelompok, bimbingan klasikal, bimbingan kelas besar/lintas kelas, konsultasi, kolaborasi, alih tangan kasus, kunjungan rumah, layanan advokasi dan konferensi kasus (Kemendikbud, 2016).

Berdasarkan hasil wawancara dengan beberapa peserta didik di SMK Negeri 4 Palangka Raya di dapatkan informasi bahwa banyak peserta didik yang belum memahami ataupun salah tafsir terkait fungsi ataupun manfaat layanan BK di sekolah. Peserta didik menganggap layanan BK di sekolah diadakan untuk menegakkan kedisiplinan peserta didik. Selain itu, peserta didik menganggap layanan BK hanya di peruntukkan hanya untuk peserta didik yang bermasalah saja. Hal ini membuat peserta didik enggan memanfaatkan layanan BK karena takut di cap "orang yang bermasalah" (Apriatama, 2018). Tentu sikap tersebut mencerminkan pemahaman yang kurang tepat karena fungsi layanan BK yang tidak hanya untuk mengentaskan permasalahan tetapi juga fungsi pemahaman, pencegahan, dan pengembangan. Pemahaman peserta didik harus segera di luruskan karena akan berdampak pada tidak berjalannya fungsi BK di sekolah. 
Pada masa pandemi Covid-19 di indonesia, Kementerian Pendidikan dan Kebudayaan membuat kebijakan untuk mengalihkan aktivitas belajar mengajar tatap muka dengan pembelajaran jarak jauh. Kebijakan tersebut di ambil untuk mengutamakan kesehatan dan keselamatan peserta didik, pendidik, tenaga kependidikan, keluarga dan masyarakat umum selama masa pandemi (GTK, 202I). Pembelajaran Jarak jauh di tambah dengan tidak ada jadwal kelas secara rutin khusus untuk Guru BK menambah kepelikan pemberian layanan BK di SMK Negeri 4 Palangka Raya. Hal tersebut mempersulit Guru BK dalam memberikan layanan BK secara konsisten dan berkelanjutan. Melihat kondisi tersebut Guru BK dituntut untuk dapat berinovasi memanfaat sumber daya teknologi untuk tetap memberikan layanan BK secara optimal di masa pandemi. Salah satu usaha yang sudah dilakukan guru BK dengan menggunakan bantuan media melalui aplikasi sosial media Whats app.

Aplikasi Whats app merupakan aplikasi messenger gratis yang bekerja dibeberapa platform seperti iphone dan android telepon, dan aplikasi ini banyak digunakan untuk mengirim pesan multimedia seperti foto, video, audio bersama dengan pesan teks sederhana. Ada beberapafitur yang terdapat dalam aplikasi Whats app yaitu fitur bertukar pesan, video, gambar dan catatan suara (Kurniawati, 20/8). Aplikasi Whats app telah banyak di gunakan oleh Guru BK dalam memberikan layanan BK pada masa pandemi yang mengharus melakukan pembelajaran jarak jauh. Melalui aplikasi Whats ApP Guru BK dapat memberikan Layanan BK khususnya layanan informasi untuk merubah pemahaman peserta didik yang kurang tepat terhadap layanan BK.

Selama ini di SMK Negeri 4 Palangka Raya melakukan sosialiasi layanan BK dengan memberikan layanan informasi. Kegiatan dilakukan dengan membagikan (sharing) powerpoint ke dalam Grup Whats App. Hasilnya pun kurang efektif karena penyampaian kurang kreatif, menarik dan tidak ada evaluasi terkait strategi tersebut. Hal tersebut membuat Guru BK harus mencari strategi lain untuk dapat memberikan layanan BK yang menarik di sekolah. Salah satu solusi yang dapat digunakan dengan menggunakan video pendek yang dibuat melalui aplikasi tiktok yang sedang trend di kalangan anak remaja.

Melihat perkembangan penggunaan sosial media sekarang, media penyampaian dengan bantuan menggunakan aplikasi tiktok menjadi hal yang sangat digandrungi usia anak muda sekarang. Aplikasi Tiktok adalah sebuah jejaring sosial dan platform video musik singkat yang dapat digunakan atau diakses melalui ponsel (Aji \& Setiyadi, 2020). Dengan penggunaan media tiktok, pengguna dapat membuat video dengan special effect yang unik dan menarik serta memiliki dukungan pilihan musik yang banyak sehingga mendorong kreativitas penggunannya untuk menciptakan video yang menarik dan tidak membosankan. Hal ini menjadikan aplikasi tiktok sebagi aplikasi dengan banyak pengguna, terlihat dari rating yang di dapatkan dari playstore 4. dari 5 bintang terbaik dengan lebih dari 10 juta pengguna di seluruh dunia. Berdasarkan penelitian 
yang dilakukan oleh (Anisa, 2017) yang memanfaatkan media sosial tiktok untuk melakukan promosi kesehatan di lingkup Fakultas kesehatan masyarakat Universitas Muhammadiyah Palu terbukti efektif untuk meningkatkan pemahaman akan kesadaran untuk hidup sehat. Selain itu hasil penelitian dari (Hutamy et al., 202I) yang menyatakan bahwa sebagian besar pesesrta didik yang notabene masuk dalam usia remaja menyukai aplikasi tik tok karena durasi video yang singkat dikemas dengan baik sehingga tidak membosankan.

Berdasarkan paparan diatas, peneliti sebagai guru BK tertarik untuk melakukan layanan informasi dengan menggunakan video yang dihasilkan oleh Aplikasi Tiktok yang akan dibagi (sharing) kepada peserta didik di Grup Whats App untuk mensosialisasikan layanan BK di SMK Negeri 4 Palangka Raya. Diharapkan dengan strategi tersebut akan berdampak pada meningkatnya pemahaman peserta didik terhadap layanan BK di sekolah.

\section{METODOLOGI}

Metode penelitian yang digunakan adala metode kualitatif dengan menggunakan pendekatan penelitian tindakan bimbingan dan konseling (PTBK). PTBK adalah penelitian yang dilakukan berdasarkan hasil reflektif yang bertujuan untuk mempelajari, mencari solusi dan memperbaiki kinerja sendiri secara sistematis, terencana dan sikap mandiri dengan suatu tindakan nyata (Apriyani et al., 2020). Artinya PTBK merupakan sebuah usaha dari guru BK untuk memantapkan ataupun memperbaiki kinerjanya. PTBK di lakukan dengan tahapan (siklus) yang paling sedikit diberikan dalam 2 siklus. Setiap siklus di awali dengan perencanaan (plan), pelaksanaan (action), pengamatan (observation) dan refleksi. teknik pengumpulan data dilakukan dengan melakukan observasi, wawancara dan angket. Teknik anaiisa data penelitian ini menggunakan teknik analisa data model Miles Huberman meliputi reduksi data, penyajian data dan penarikan kesimpulan (Sugiyono, 2018).

\section{HASIL DAN PEMBAHASAN}

Sebelum masuk pada langkah-langkah siklus, terlebih dahulu peneliti melakukan refleksi terkait sosialiasi layanan BK yang dilakukan di SMK Negeri 4 Palangka Raya. Refleksi dilakukan dengan melakukan wawancara dan angket. Wawancara dilakukan dengan 10 (sepuluh) peserta didik untuk meminta masukan atau feedback pada penerima sosialisasi yaitu peserta didik. Ada beberapa informasi yang didapatkan dari peserta didik terkait sosialiasi melalui Whats App Group dengan memberikan materi Powerpoint. Hasilnya beberapa peserta didik masih banyak yang belum memahami materi. Selain itu peserta didik berpendapat pemberian dengan materi dengan powerpoint kurang menarik dan membosankan. Selanjutnya hasil angket persepsi peserta didik terhadap bimbingan dan konseling diberikan kepada 86 peserta didik di SMK Negeri 4 Palangka Raya. Hasilnya 52,33 \% menyatakan pemahaman yang kurang baik terhadap layanan BK seperti mengganggap bahwa layanan BK hanya untuk siswa bermasalah saja, Bk tempat yang 
menakutkan, BK adalah tempat pemberian hukuman dan yang melanggar peraturan.

Pemahaman siswa yang rendah terhadap layanan BK menyebabkan peserta didik enggan untuk memanfaatkan layanan BK di sekolah. Peneliti hal tersebut harus segera dituntaskan karena akan menyebabkan banyak permasalahan peserta didik seperti masalah pribadi, sosial, karir dan belajar tidak tertangani yang akan menyebabkan peserta didik kurang optimal dalam menerima pembelajaraan di sekolah karena banyak gangguan dan hambatan.

\section{Siklus I}

\section{Perencanaan}

Adapun langkah-langkah yang dilakukan pada tahap perencanaan sebagai berikut:

I) Diskusi dengan teman sejawat di sekolah

2) Menentukan kegiatan, waktu dan tempat konseling

3) Menyiapkan RPL (rencana Pelaksanaan Layanan)

4) Menentukan teknik, strategi, media dan layanan informasi

\section{Pelaksanaan}

Pelaksanaan layanan dilakukan dengan menyampaikan layanan informasi melalui whats app group dengan menggunakan video yang di hasilkan dari video tiktok yang menginformasi tentang layanan bimbingan dan konseling. Langkah-langkah yang dilakukan sebagai berikut:

I) Mengkondisikan semua peserta didik sebelum memulai layanan informasi
2) Mengucapkan salam

3) Mengajak untuk berdoa sebelum memulai kegiatan

4) Menanyakan kabar peserta didik

5) Menjelaskan maksud dan tujuan layanan informasi

6) Menanyakan apersepsi pemahaman peserta didik terhadap lyanan bimbingan dan konseling di sekolah

7) Mengirimkan video ke group Whats app Group sebagai bahan diskusi

8) Mengajak peserta didik untuk berdiskusi setelah menonton video

9) Memberikan kesimpulan

10) Melakukan evaluasi dengan meminta peserta didik untuk mengisi angket yang dibagikan melalui google form untuk mengukur pemahaman peserta didik terhadap layanan BK

\section{Pengamatan}

Langkah-langkah pengamatan pada group whats app dilakukan sebagai berikut:

I) Mengamati keaktifan dan antusiame peserta didik mengikuti layanan informasi

2) Mengamati respon yang di tunjukkan peserta didik setelah menonton video

\section{Refleksi}

Refleksi pada siklus I dilakukan dengan melihat kekurangan atau hambatan yang terjadi dalam pemberian layanan informasi. Selain itu untuk melihat keberhasilan layanan informasi sebagai 
usaha intervensi untuk meningkatkan pemahaman peserta didik terhadap layanan BK di sekolah dilakukan dengan melihat skor angket. Adapun hambatan-hambatan yang terjadi sebagai berikut:

I) Tidak semua peserta didik aktif dalam mengikuti kegiatan layanan informasi terlihat dari jumlah views video. Dari 86 peserta didik hanya 75 peserta didik yang menonton video, yang berarti masih ada II peserta didik yang tidak menonton video. Setelah di konfirmasi kepada peserta didik, mereka tidak menontin video karena tertinggal informasi karena kurang aktif melihat notifikasi atau pemberitahuan pesan yang masuk whats App Group sehingga menyebabkan peserta didik banyak tertinggal informasi.

2) Dari semua 86 peserta didik ada 79 peserta didik yang mengisi angket yang berarti masih ada 6 peserta didik yang tidak mengisi angket. Setelah di konfirmasi banyak peserta didik yang kurang mengerti bagaimana cara untuk mengisi angket tersebut yang menyebabkan peserta didik memilih untuk tidak mengisi angket.

Hambatan-hambatan di atas akan di atasi dengan pada siklus 2 dengan seperti menginformasi tata cara dalam mengikuti layanan informasi 2 (hari) sebelum kegiatan layanan informasi dilakukan. Selain itu, I jam sebelum memulai kegiatan, guru BK akan mengingatkan kembali jadwal kegiatan layanan konseling kepada peserta didik melalui whats app group.
Adapun hasil angket pada siklus I menunjukkan perubahan signifikan. Ada kenaikan $27 \%$ dari hasil sebelumnya yang berada pada persentase $52 \%$. Yang berarti secara keseluruhan dari 86 peserta didik SMK Negeri 4 Palangka Raya ada 79\% peserta didik yang sudah memahami secara baik tujuan dan manfaat layanan BK di sekolah.

\section{Siklus II}

\section{Perencanaan}

Adapun langkah-langkah yang dilakukan pada tahap perencanaan sebagai berikut:

I) Diskusi dengan teman sejawat di sekolah

2) Menentukan kegiatan, waktu dan tempat layanan informasi

3) Menyusun tata cara atau panduan peserta didik dalam mengikuti layanan informasi

4) Melakukan sosialiasi kegiatan, waktu dan tempat layanan informasi kepada peserta didik

5) Menyiapkan RPL (rencana Pelaksanaan Layanan)

6) Menentukan teknik, strategi, media dan layanan informasi

Perubahan dilakukan dengan menyusun tata cara atau panduan serta melakukan kepada peserta didik untuk mengatasi peserta didik yang kebingungan dalam mengikuti layanan informasi. Selain sosialisasi 3 hari dan I jam sebelum kegiatan di mulai untuk memberikan informasi terkait jadwal dan tata cara mengikuti layanan informasi 


\section{Pelaksanaan}

Pemberian layanan informasi dilakukan seperti pada siklus I dengan perubahan-perubahan. Adapun langkah-langkahnya sebagai berikut:

I) Mengkondisikan semua peserta didik sebelum memulai layanan informasi

2) Mengucapkan salam

3) Mengajak untuk berdoa sebelum memulai kegiatan

4) Menanyakan kabar peserta didik

5) Menjelaskan maksud dan tujuan layanan informasi

6) Menanyakan apersepsi pemahaman peserta didik terhadap layanan bimbingan dan konseling di sekolah

7) Mengirimkan video ke group Whats app Group sebagai bahan diskusi

8) Mengajak peserta didik untuk berdiskusi setelah menonton video

9) Memberikan kesimpulan

10) Melakukan evaluasi dengan meminta peserta didik untuk mengisi angket yang dibagikan melalui google form untuk mengukur pemahaman peserta didik terhadap layanan BK.

Perubahan dilakukan dengan menginformasi ke group tentang peserta didik yang belum mengisi angket. Selanjutnya peserta dihimbau untuk segera mengisi angket sebagai bahan evaluasi.

\section{Pengamatan}

Langkah-langkah pengamatan pada group whats app dilakukan sebagai berikut:
I) Mengamati keaktifan dan antusiame peserta didik mengikuti layanan informasi

2) Mengamati respon yang di tunjukkan peserta didik setelah menonton video

\section{Refleksi}

Refleksi pada siklus II dilakukan dengan melihat kekurangan atau hambatan yang terjadi dalam pada siklus I. Adapun hambatan-hambatan yang terjadi pada siklus I telah di atasi dengan berbagai strategi yang dilakukan oleh peneliti dan terjadi perubahan sebagai berikut:

I) Semua peserta didik aktif dalam mengikuti kegiatan layanan informasi terlihat dari jumlah views video yang berjumlah 86 peserta didik telah menonton video yang dibagikan

2) Seluruh peserta didik yang berjumlah 86 peserta didik telah mengisi angket yang dibagikan melalui google form.

Adapun hasil angket pada siklus II menunjukkan perubahan signifikan. Ada kenaikan II\% dari hasil sebelumnya pada siklus II yang berada pada persentase 79\%. Yang berarti secara keseluruhan dari 86 peserta didik SMK Negeri 4 Palangka Raya ada $89 \%$ peserta didik yang sudah sangat baik memahami tujuan dan manfaat layanan BK di sekolah.

Dari 2 siklus yang telah dilakukan peneliti menyimpulkan bahwa ada peningkatan pemahaman peserta didik terhadap pemberian layanan BK di sekolah sebesar 37\%. Peningkatan 
itu di lihat dari skor angket sebelum PTBK di laksanakan yang hasilnya hanya $52 \%$. setelah PTBK dilaksanakan hasilnya mencapai sampai $89 \%$. Artinya kegiatan layanan informasi dengan menggunakan video tiktok secara efektif meningkatkan pemahaman peserta didik terhadap layanan BK di SMK Negeri 4 Palangka Raya. Hasil tersebut juga menguatkan hasil penelitian yang dilakukan oleh (Anisa, 2017) yang memanfaatkan media sosial tiktok untuk melakukan promosi kesehatan di lingkup Fakultas kesehatan masyarakat Universitas Muhammadiyah Palu terbukti efektif untuk meningkatkan pemahaman akan kesadaran untuk hidup sehat. Selain itu hasil penelitian dari (Hutamy et al., 202I) yang menyatakan bahwa sebagian besar peserta didik yang notabene masuk dalam usia remaja menyukai aplikasi tik tok karena durasi video yang singkat dikemas dengan baik sehingga tidak membosankan.

\section{KESIMPULAN}

Berdasarkan hasil penelitian dan pembahasan peneliti menyimpulkan pemahaman peserta didik yang rendah terhadap layanan BK di sekolah dapat ditingkatkan dengan pemberian layanan informasi dengan menggunakan hasil dari video tiktok melalui Aplikasi Whats App. Hal tersebut di buktikan dengan hasil pengamatan dan angket pemahaman peserta didik terhadap layanan BK.

Dari pengamatan terdapat siswa secara aktif dan antusias mengikuti kegiatan tersebut yang di lihat melalui jumlah views video dan respon komentar dalam aplikasi whats app. Lebih khusus lagi peningkatan dapat dilihat melalui kenaikan skor angket yang sebelum diberikan intervensi hanya mencapai $52 \%$, setelah diberikan layanan informasi dengan video tiktok dengan 2 siklus meningkatnya menjadi $89 \%$. Artinya ada peningkatan sebesar $37 \%$. Peneliti berharap pada peneliti selanjutnya dapat mengembangkan strategi dengan bantuan video tiktok terutama dalam meningkatkan pemahaman peserta didik terhadap layanan BK di sekolah.

\section{REFERENSI}

Aji, W. N., \& Setiyadi, D. B. P. (2020). Aplikasi Tik Tok Sebagai Media Pembelajaran Keterampilan Bersastra. Metafora: Jurnal Pembelajaran Bahasa Dan Sastra, 6(2), I47157.

Anisa, N. (2017). Related Papers. Over The Rim, 191-199. https://doi.org// 0.2307/j.ctt46nrzt. 12

Apriatama, D. (2018). Faktor-Faktor Yang Menghambat Siswa Dalam Memanfaatkan Layanan Informasi Karir Di SMP Negeri 6 Palangkaraya. Juenal Bimbingan Dan Konseling Indonesia, 3(2), 43-48.

Apriyani, D., Bhakti, C. P., \& Bandono, B. (2020). UPAYA PENINGKATKAN MANAJEMEN EMOSI MELALUI BIMBINGAN KLASIKAL DENGAN TEKNIK SOSIODRAMA PADA SISWA KELAS $X$ TKR SMK MUHAMMADIYAH 6 KARANGANYAR TAHUN 2020/202I.

GTK, D. (202I). GTK Kemdikbud | Kebijakan Kemendikbud di Masa Pandemi. https://gtk.kemdikbud.go.id/readnews/kebijakan-kemendikbud-di-masa- 
pandemi

Hutamy, E. T., Swartika, F., Alisyahbana, A. N. Q.

A., Arisah, N., \& Hasan, M. (202I). PERSEPSI

PESERTA DIDIK TERHADAP

PEMANFAATAN TIK TOK SEBAGAI

MEDIA PEMBELAJARAN. Prosiding Penelitian

Pendidikan Dan Pengabdian 202 I, I (I), I270-

|28I.

Kemendikbud. (2016). PANDUAN OPERASIONAL

PENYELENGGARAAN BIMBINGAN DAN

KONSELING.

Kurniawati, R. D. (2018). PENGARUH

PENGEMBANGAN PROGRAM LAYANAN

BIMBINGAN KELOMPOK MELALUI MEDIA BK

BERBASIS WHATSAPP SEBAGAI TINDAKAN

PREVENTIF TERHADAP KENAKALAN REMAJA

(Penelitian pada Siswa Kelas IX SMP Negeri 13

Kota Magelang). Skripsi, Universitas

Muhammadiyah Magelang.

Nurihsan, A. J. (2016). Bimbingan dan Konseling:

dalam berbagai latar kehidupan. Refika

Aditama.

Rahmawati, F., \& Handoyo, A. W. (2020).

Peningkatan Pemahaman Peserta Didik

Terhadap Layanan Dan Peran Bimbingan

Dan Konseling. Jurnal Penelitian Bimbingan

Dan Konseling, 5(2), 53-58.

Sugiyono. (2018). Metode Penelitian

Kuantitatif,Kualitatif dan R\&D. In ke-26. 